\title{
Ovarian-Adrenal Interactions in Regulation of Endocrine Pancreatic Function in the Rat
}

\author{
A. Faure' ${ }^{1}$ M.-T.Sutter-Dub ${ }^{1}$, B.C.J. Sutter ${ }^{1}$ and R. Assan ${ }^{2}$ \\ ${ }^{1}$ Laboratoire de Physiologie Animale: Endocrinologie, UER de Biologie, Université de Bordeaux I, Talence and \\ ${ }^{2}$ Service de Diabétologie et Endocrinologie, Hôpital Bichat, Paris, France
}

\begin{abstract}
Summary. The interference of adrenal hormones with the oestradiol-induced modifications of endocrine pancreatic function remains controversial. For this reason, we compared sham-operated, ovariectomized and adrenalectomized-ovariectomized female rats. In each group, control and 17- $\beta$-oestradiol-treated rats $(0.1 \mathrm{mg} /$ day for 14 days $)$ were studied, the latter group being compared with similar rats treated with corticosterone $(0.4 \mathrm{mg} /$ day $)$. Oestradiol treatment induced hypoglycaemia and hyperinsulinism in basal and glucose-stimulated states, and hypoglucagonaemia. The presence of adrenal glands was necessary for the full expression of oestradiol effects on pancreatic islet B cells: in adrenalectomized-ovariectomized rats, oestradiol treatment induced an unexpected de-
\end{abstract}

crease in insulin response to intravenous glucose, and in pancreatic insulin content. Corticosterone treatment partly restored the oestradiol-induced rise of plasma insulin, and restored the B cell response to intravenous glucose. A permissive action of glucocorticoids may be a prerequisite for the effect of oestrogens on B cells. Since oestrogens by themselves augment the plasma corticosterone level, the insulinotropic effect of oestrogens may be partly mediated by the increase in endogenous corticosteroids. In contrast, oestradiol seems to suppress islet A cell function.

Key words: Oestradiol treatment, rat, ovariectomy, adrenalectomy, plasma glucose, plasma insulin, plasma glucagon.
Oestrogens can modify the structure and function of islet cells in a variety of physiological and experimental conditions [1-5]. The main modification induced by oestradiol consists of an increased insulin release and decreased A cell function [6-8]. Glucocorticoid treatment similarly increases the concentration of plasma insulin [9-12] and can decrease that of glucagon [12]. Since oestrogen treatment causes an increase in plasma corticoid level [13-15], it has been postulated that the oestrogen effect on the islets can be, at least partly, mediated by glucocorticoid release $[8,13,14,16-18]$. In order to test this hypothesis, effects of a 14-day oestradiol treatment $\left(\mathrm{E}_{2}\right)$ on islet function were examined in normal, ovariectomized, and adrenalectomized-ovariectomized rats, with or without corticosterone supplementation.

\section{Methods}

\section{Animals}

Female Wistar rats $(200-210 \mathrm{~g})$ were kept in a temperature-controlled room at $22{ }^{\circ} \mathrm{C}$ with a 12 -h lighting schedule $(07.00-19.00 \mathrm{~h})$ and free access to standard laboratory chow and water. A $0.9 \% \mathrm{NaCl}$ solution in water was substituted for water after adrenalectomy. Body weight and food ingestion were monitored throughout the study. The animals were divided into four groups: (1) sham-operated, (2) ovariectomized, (3) adrenalectomized-ovariectomized and (4) adrenalectomized-ovariectomized-corticosterone-treated. After a 8-day post-operative recovery period, the rats received $\mathrm{SC}$ injections of $17-\beta$-oestradiol twice daily for 14 days (Sigma Chemicals, St. Louis, USA). This hormone was dissolved in ethanol and olive oil $(2.5 / 97.5, \mathrm{v} / \mathrm{v})$ to a final concentration of $0.05 \mathrm{mg}$ in $0.1 \mathrm{ml}$, supplemented or not with corticosterone (Fluka, Buchs, Switzerland). The dosage of corticosterone was $0.2 \mathrm{mg}$ twice daily; control animals received vehicle alone. The last injection was given $20 \mathrm{~h}$ before each study to avoid oil interference with fasting.

\section{Experimental Procedures}

Intravenous glucose tolerance tests were performed under pentobarbital anaesthesia $(5 \mathrm{mg} / 100 \mathrm{~g}$ body weight, IP) on animals fasted for $20 \mathrm{~h}$. A polyethylene catheter was inserted into the jugular vein and kept patent with use of heparin (Choay, Paris, $50 \mathrm{U} / \mathrm{kg}$ body weight). Twenty minutes later blood samples $(300 \mu \mathrm{l})$ were collected in $1-\mathrm{U}$ dried heparinized microtubes at zero time and 2,10,20 and $40 \mathrm{~min}$ after an IV injection of glucose $(300 \mathrm{mg} / \mathrm{ml} ; 0.1 \mathrm{ml} / 100 \mathrm{~g}$ body weight). All the solutions used were at $37^{\circ} \mathrm{C}$ and the animals were maintained euthermic.

Blood samples from fed rats were collected after decapitation between 09.00 and $10.00 \mathrm{~h}$ into dried heparinized tubes $(1 \mathrm{U})$. For glucagon assays, $500 \mathrm{U}$ iniprol (Choay, Paris) had been added to heparin. 
Table 1. Body weight, food intake and fluid intake of each group of rats

\begin{tabular}{|c|c|c|c|c|c|c|c|c|c|c|}
\hline & \multirow{2}{*}{$\begin{array}{l}\text { Number of } \\
\text { determina- } \\
\text { tions }\end{array}$} & \multicolumn{3}{|c|}{ Body weight (g) } & \multicolumn{3}{|c|}{ Food intake (g/day) } & \multicolumn{3}{|c|}{ Fluid intake (ml/day) } \\
\hline & & $\begin{array}{l}\text { Before } \\
\text { operation }\end{array}$ & $\begin{array}{l}\text { Before } \\
\text { treatment }\end{array}$ & $\begin{array}{l}\text { Day } 14 \text { of } \\
\text { treatment }\end{array}$ & $\begin{array}{l}\text { Before } \\
\text { operation }\end{array}$ & $\begin{array}{l}\text { Before } \\
\text { treatment }\end{array}$ & $\begin{array}{l}\text { Day } 14 \text { of } \\
\text { treatment }\end{array}$ & $\begin{array}{l}\text { Before } \\
\text { opera- } \\
\text { tion }\end{array}$ & $\begin{array}{l}\text { Before } \\
\text { treat- } \\
\text { ment }\end{array}$ & $\begin{array}{l}\text { Day } 14 \text { of } \\
\text { treatment }\end{array}$ \\
\hline \multicolumn{11}{|l|}{ Oil-treated rats } \\
\hline Sham-operated & 9 & $205 \pm 2$ & $215 \pm 3$ & $229 \pm 15$ & $15.5 \pm 0.4$ & $17.4 \pm 0.1$ & $17.7 \pm 1.5$ & $21 \pm 1$ & $23 \pm 1$ & $25 \pm 2$ \\
\hline Ovariectomized & 14 & $210 \pm 2$ & $218 \pm 3$ & $257 \pm 5^{a}$ & $16.9 \pm 0.9$ & $16.7 \pm 0.5$ & $20.3 \pm 0.2$ & $20 \pm 1$ & $19 \pm 1$ & $21 \pm 1$ \\
\hline $\begin{array}{l}\text { Adrenalectomized- } \\
\text { ovariectomized }\end{array}$ & 9 & $209 \pm 3$ & $208 \pm 3$ & $237 \pm 8$ & $16.1 \pm 1.8$ & $15.7 \pm 0.6$ & $17.9 \pm 1.1$ & $18 \pm 1$ & $24 \pm 2^{\mathrm{i}}$ & $44 \pm 6^{b, c, i}$ \\
\hline $\begin{array}{l}\text { Adrenalectomized- } \\
\text { ovariectomized } \\
+ \text { corticosterone }\end{array}$ & 6 & $202 \pm 5$ & $200 \pm 9$ & $231 \pm 8$ & $16.5 \pm 0.7$ & $16.3 \pm 0.6$ & $17.3 \pm 0.4$ & $19 \pm 1$ & $23 \pm 3^{i}$ & $44 \pm 5^{\mathrm{b}, \mathrm{c}, \mathrm{i}}$ \\
\hline \multicolumn{11}{|l|}{ Oestradiol-treated rats } \\
\hline Sham-operated & 9 & $204 \pm 3$ & $213 \pm 3$ & $227 \pm 7$ & $15.8 \pm 0.7$ & $16.0 \pm 1.0$ & $15.3 \pm 0.9$ & $21 \pm 1$ & $21 \pm 1$ & $30 \pm 2$ \\
\hline Ovariectomized & 15 & $210 \pm 2$ & $217 \pm 3$ & $220 \pm 4^{h}$ & $16.9 \pm 0.4$ & $17.3 \pm 0.2$ & $14.1 \pm 1.0^{\mathrm{h}}$ & $21 \pm 1$ & $20 \pm 1$ & $37 \pm 6^{\mathrm{d}, \mathrm{g}}$ \\
\hline $\begin{array}{l}\text { Adrenalectomized- } \\
\text { ovariectomized }\end{array}$ & 7 & $210 \pm 5$ & $209 \pm 5$ & $219 \pm 7$ & $17.6 \pm 0.9$ & $15.1 \pm 1.3$ & $13.3 \pm 1.4^{f}$ & $19 \pm 2$ & $23 \pm 2^{i}$ & $43 \pm 8^{e}$ \\
\hline $\begin{array}{l}\text { Adrenalectomized- } \\
\text { ovariectomized } \\
+ \text { corticosterone }\end{array}$ & 7 & $209 \pm 3$ & $207 \pm 5$ & $212 \pm 5$ & $16.9 \pm 0.9$ & $15.8 \pm 1.5$ & $12.6 \pm 0.4^{\mathrm{h}}$ & $20 \pm 1$ & $24 \pm 2^{i}$ & $40 \pm 6^{\mathrm{e}}$ \\
\hline
\end{tabular}

Results presented are those before operation, 8 days later after a recovery period but before treatment, and on day 14 of oil or oestradiol ( $\left.E_{2}\right)$ treatment in sham-operated, ovariectomized and adrenalectomized-ovariectomized rats supplemented or not with corticosterone. Results expressed as mean $\pm \mathrm{SEM} ;{ }^{\mathrm{a}} p<0.01$ versus sham oil-treated control rats; ${ }^{\mathrm{b}} p<0.001$ versus sham-operated oil-treated control rats; ${ }^{\mathrm{c}} p<0.001$ versus ovariectomized-oil-treated control rats; ${ }^{\mathrm{d}} p<0.01$ versus $\mathrm{E}_{2}$-treated sham group; ${ }^{\mathrm{e}} p<0.001$ versus $\mathrm{E}_{2}$-treated sham group; ${ }^{\mathrm{f}} p<0.05 ;{ }^{\mathrm{g}} p<0.01$; ${ }^{\mathrm{h}} p<0.001$ versus respective oil-treated control groups; ${ }^{\mathrm{i}}$ water was replaced by $\mathrm{NaCl} 0.9 \%$ solution in water.

After centrifugation at $4{ }^{\circ} \mathrm{C}$, plasma samples were frozen at $-20^{\circ} \mathrm{C}$ until assay.

Pancreatic insulin was extracted by acidified ethanol $(\mathrm{HCl}$ $1 \mathrm{~mol} / \mathrm{l}$; ethanol, $1: 5, \mathrm{v} / \mathrm{v}), 20 \mathrm{ml} / \mathrm{g}$ wet pancreas; $0.5 \mathrm{ml}$ of this extract was precipitated by $2 \mathrm{ml}$ ether-ethanol $(2: 1, \mathrm{v} / \mathrm{v}, \mathrm{pH} 8.5)$, then redissolved in $1 \mathrm{ml}$ acetic acid $(1 \mathrm{~mol} / 1)$ and diluted $(\times 500)$ before insulin assay. Results were corrected by a $73 \%$ extraction yield, assessed from ten ${ }^{125}$-iodinated insulin samples run in parallel.

\section{Analytical Methods}

Glucose was measured by a glucose oxidase method [19] and insulin by radioimmunoassay [20] using rat insulin as a standard (Novo, Copenhagen, Denmark). Sensitivity of the insulin assay was $3 \mathrm{mU} / 1$ for values lower than $25 \mathrm{mU} / 1$, with a coefficient of variation of $21 \%$; and $13 \mathrm{mU} / 1$ with coefficient of variation of $7 \%$ for values lower than $125 \mathrm{mU} / 1$. Glucagon was determinated by a radioimmunoassay technique [21] using $30 \mathrm{~K}$ anti-serum (from Dr. R. Unger, Dallas, Texas) with a sensitivity of $21 \mathrm{pg} / \mathrm{ml}$ and a whole plasma coefficient of variation $<15 \%$. Progesterone and oestradiol were assayed by radioimmunoassay methods $[22,23]$ with sensitivities of $20 \mathrm{pg} / \mathrm{ml}$ and $0.1 \mathrm{ng} / \mathrm{ml}$ respectively, interassay coefficients of variation being $<15 \%$. In control rats, samples for these measurements were collected at time of oestrus. Corticosterone was measured by a competitive-protein binding assay [24] using 5\% dog plasma, after dichloromethane extraction and paper chromatography with solvent system Bush B5. Sensitivity was $0.14 \mathrm{ng} / \mathrm{ml}$, coefficient of variation $7 \%$, and extraction coefficient $58 \%$. Interference with the oestradiol assay was $<0.003 \%$ for corticosterone and progesterone, and $<1 \%$ for oestrone and oestriol. Interference with the progesterone assay was $<7 \%$ for desoxycorticosterone, $<3 \%$ for dihydro- and hydroxyprogesterone, and $<0.001 \%$ for oestradiol or cortisol. Percentage of bound corticosterone or progesterone was determined by an equilibrium dialysis technique [25] adapted to small plasma volumes [26]. Plasma volume was measured in five control and five $E_{2}$-treated animals by the Evans blue plasma diffusion technique (after IV injection of $0.2 \mathrm{ml}$ of $0.25 \%$ Evans blue solution in $0.9 \% \mathrm{NaCl}$ ).

\section{Calculations}

Results are expressed as mean \pm SEM. Statistical significance of differences was established using the Student's t-test for unpaired samples. Glucose disappearance coefficient $\left(\mathrm{K}_{\mathrm{G}}\right)$ was calculated from time 2 to $40 \mathrm{~min}$ from formula: $K_{G}=\frac{\log _{e} \mathrm{C}-\log _{\mathrm{e}} \frac{\mathrm{C}}{2}}{\mathrm{t}}=\frac{0.693}{\mathrm{t}}$ where $\mathrm{t}$ is the time ( $\mathrm{min}$ ) necessary for glucose rate to fall from concentration $\mathrm{C}$ to $\frac{\mathrm{C}}{2}(\mathrm{~g} / \mathrm{l})$. Insulin response curve areas were evaluated by trapezoidal integration from time 0 to $40 \mathrm{~min}(\mathrm{mU} / 1 \times 40 \mathrm{~min})$.

\section{Results}

\section{Body Weight, Food and Fluid Intake (Table 1)}

There was no difference between the various groups in body weight before treatment, i. e. after a 8-day post-operative recovery period. On day 14 of treatment, weight gain was significant in the oil-treated ovariectomized rats (Table 1). Food intake decreased transiently during the 2 days following surgery in all groups. No further variation occurred in oil-treated rats. All $\mathrm{E}_{2}$-treated rats displayed a decrease in food intake for the first 6 days of $\mathrm{E}_{2}$ treatment. A subsequent increase towards control levels occurred later in sham-operated- $\mathrm{E}_{2}$-treated rats; slight but significant differences persisted in other $\mathrm{E}_{2^{-}}$ treated groups (Table 1).

Fluid intake was not significantly affected by surgery itself. It increased after a few days in adrenalectomized-ovariectomized animals. The $E_{2}$ treatment in- 
Table 2. Plasma oestradiol, progesterone, corticosterone and plasma volume in each group of rats

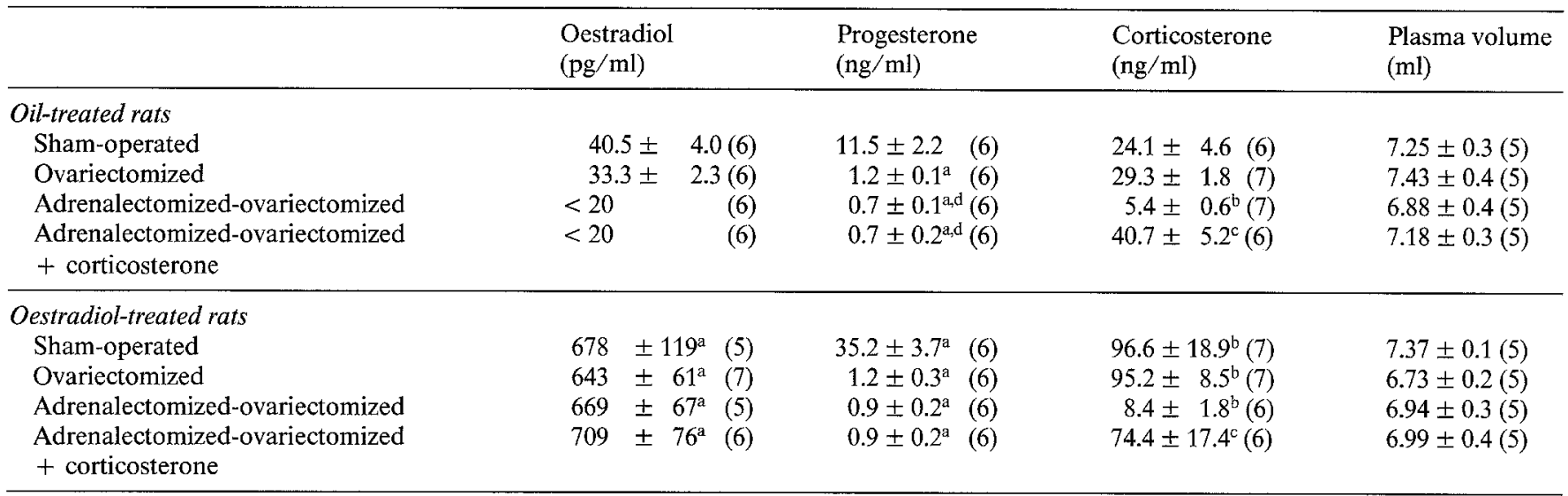

Results presented are those of oil or oestradiol $\left(\mathrm{E}_{2}\right)$ treated rats after 14 days. Results expressed as mean \pm SEM (number of determinations in parentheses); ${ }^{\mathrm{a}} p<0.001 ;{ }^{\mathrm{b}} p<0.01 ;{ }^{\mathrm{c}} p<0.05$ versus sham-operated control rats; ${ }^{\mathrm{d}} p<0.05$ versus ovariectomized control rats

Table 3. Responses to intravenous glucose loading

\begin{tabular}{|c|c|c|c|c|c|}
\hline & $\begin{array}{l}\text { Number of deter- } \\
\text { minations }\end{array}$ & $\begin{array}{l}\text { Fasting plasma } \\
\text { glucose }(\mathrm{mmol} / \mathrm{l})\end{array}$ & $\begin{array}{l}\text { Fasting plasma } \\
\text { insulin }(\mathrm{m} U / 1)\end{array}$ & $\begin{array}{l}\text { Area of insulin } \\
\text { response during } \\
\text { test }(\mathrm{mU} / 1 \times 40 \mathrm{~min})\end{array}$ & $\begin{array}{l}\text { Glucose disap- } \\
\text { pearance coef- } \\
\text { ficient } \\
\left(\mathbf{K}_{\mathrm{G}} 10^{2} / \mathrm{min}^{-1}\right)\end{array}$ \\
\hline \multicolumn{6}{|l|}{ Oil-treated rats } \\
\hline Sham-operated & 9 & $5.3 \pm 0.3$ & $16 \pm 3$ & $2801 \pm 261$ & $2.47 \pm 0.07$ \\
\hline Ovariectomized & 10 & $5.4 \pm 0.2$ & $17 \pm 1$ & $2528 \pm 296$ & $2.26 \pm 0.09$ \\
\hline Adrenalectomized-ovariectomized & 16 & $4.4 \pm 0.1^{\mathrm{b}, \mathrm{e}}$ & $3 \pm 1^{\mathrm{c}, \mathrm{f}}$ & $1954 \pm 209^{b}$ & $1.89 \pm 0.10^{\mathrm{c} d}$ \\
\hline \multicolumn{6}{|l|}{ Oestradiol-treated rats } \\
\hline Sham-operated & 8 & $4.8 \pm 0.2$ & $22 \pm 2^{m}$ & $3429 \pm 197^{1}$ & $2.29 \pm 0.06$ \\
\hline Ovariectomized & 13 & $4.8 \pm 0.3$ & $28 \pm 1^{1}$ & $3788 \pm 224^{\mathrm{m}}$ & $2.45 \pm 0.06$ \\
\hline Adrenalectomized-ovariectomized & 11 & $3.6 \pm 0.3^{\mathrm{a}, \mathrm{h}}$ & $7 \pm 3^{\mathrm{a}, \mathrm{i}}$ & $1058 \pm 148^{\mathrm{ci}, \mathrm{m}}$ & $1.78 \pm 0.14^{\mathrm{c} i \mathrm{i}}$ \\
\hline $\begin{array}{l}\text { Adrenalectomized-ovariectomized } \\
+ \text { corticosterone }\end{array}$ & 6 & $6.1 \pm 0.2^{\mathrm{i}, \mathrm{k}, \mathrm{m}}$ & $9 \pm 2^{a, j, 1}$ & $1912 \pm 290^{\mathrm{j}, \mathrm{n}}$ & $1.44 \pm 0.09^{\mathrm{c} f \mathrm{f,in}}$ \\
\hline
\end{tabular}

Results expressed as mean \pm SEM. For details of procedure see text: ${ }^{\mathrm{a}} p<0.05 ;{ }^{\mathrm{b}} p<0.01 ;{ }^{\mathrm{c}} p<0.001$ versus sham control rats; ${ }^{\mathrm{d}} p<0.05 ;{ }^{\mathrm{e}} p<$ $0.01 ;{ }^{\mathrm{f}} p<0.001$ versus ovariectomized control rats; ${ }^{\mathrm{g}} p<0.001$ versus ovariectomized-adrenalectomized control group; ${ }^{\mathrm{h}} p<0.05 ;{ }^{\mathrm{i}} p<0.001$ versus sham and ovariectomized $\mathrm{E}_{2}$-treated rats; ${ }^{\mathrm{j}} p<0.01$ versus $\mathrm{E}_{2}$-treated adrenalectomized-ovariectomized rats and $p<0.001$ versus $\mathrm{E}_{2}$-treated sham or ovariectomized rats; ${ }^{\mathrm{k}} p<0.001$ versus $\mathrm{E}_{2}$-treated adrenalectomized-ovariectomized rats; ${ }^{\mathrm{h}} p<0.05$; ${ }^{\mathrm{m}} p<0.01$; ${ }^{\mathrm{n}} p<0.001$ versus respective oil control groups

creased fluid intake in the ovariectomized rats and even more in the adrenalectomized-ovariectomized group (Table 1).

\section{Plasma Volume and Steroid Concentrations}

Rat plasma volume was not modified by the various treatments (Table 2).

Plasma oestradiol concentration was, for the control group, in the normal range for the time of oestrus. In ovariectomized rats, plasma oestradiol did not decrease significantly. In contrast, it became unmeasurable in adrenalectomized-ovariectomized rats. In $\mathrm{E}_{2}$-treated groups, plasma oestradiol levels were higher than normal values for non-pregnant rats, in the range of late gestational values $(683 \pm 60 \mathrm{pg} / \mathrm{ml} ; n=6$ on day 20 of gestation).
Plasma progesterone in control rats was $11.5 \pm$ $2.2 \mathrm{ng} / \mathrm{ml}$, a value consistent with early oestrus. It was very low after ovariectomy and even lower after adrenalectomy in oil and $\mathrm{E}_{2}$-treated groups. It was threefold higher than the control value in sham-operated $\mathrm{E}_{2}$-treated rats. The percentage of bound progesterone was not modified by $\mathrm{E}_{2}$ treatment $(89.7 \pm 0.5$ versus $88.8 \pm$ $0.4 \% ; n=4$ in each group).

Plasma corticosterone was in the normal range for the control and ovariectomized rats, but it declined dramatically in all adrenalectomized rats but remained detectable. In non-adrenalectomized rats, $\mathrm{E}_{2}$ treatment induced a fourfold increase in plasma corticosterone level. The proportion of bound hormone was not modified by this treatment: $91.3 \pm 0.6 \%$ in untreated versus $90.1 \pm 0.5 \%$ in $E_{2}$-treated sham-operated rats, and 90.0 $\pm 0.8 \%$ versus $86.9 \pm 0.5 \%$ for the corresponding cas- 

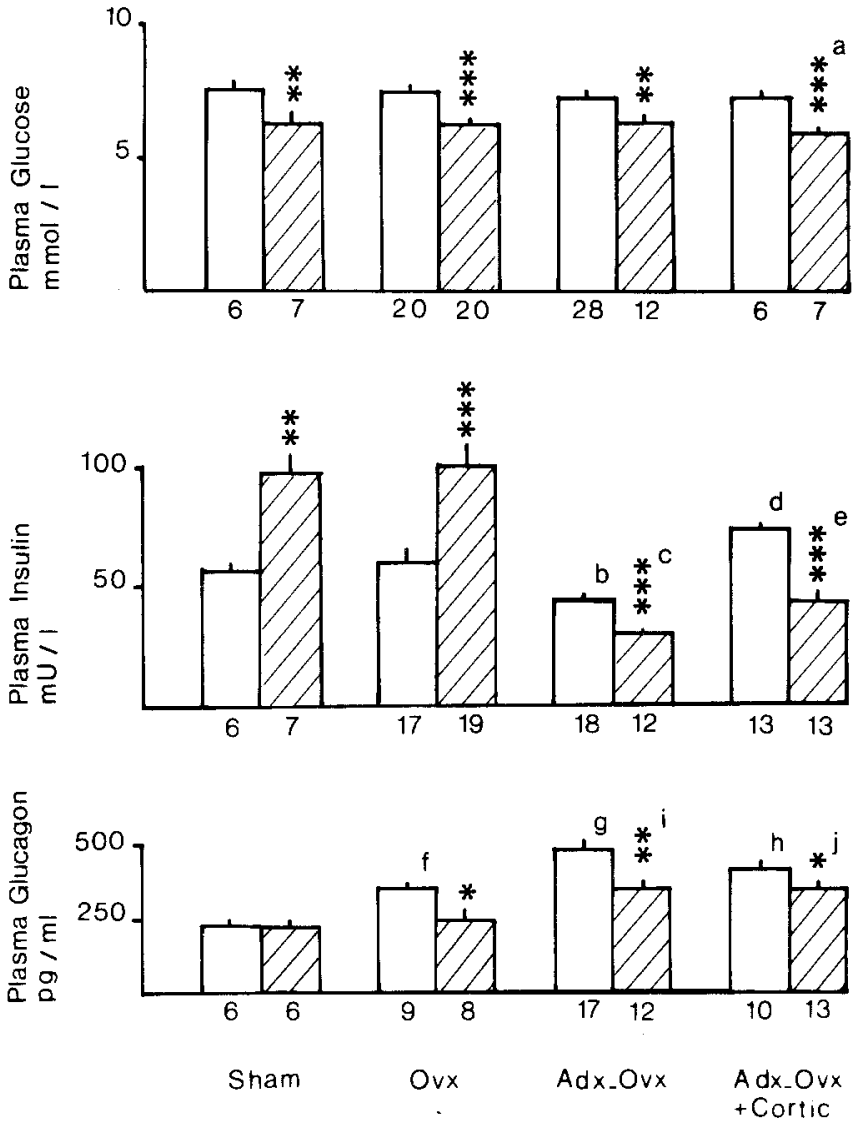

Fig. 1. Plasma glucose, insulin and glucagon levels from fed rats, oil $\square$ or oestradiol $\left(\mathrm{E}_{2}\right)$-treated for 14 days, in four groups of animals: sham-operated (Sham), ovariectomized (Ovx), adrenalectomizedovariectomized (Adx-Ovx) supplemented or not with corticosterone ( + Cortic). Values are mean \pm SEM; number of results indicated under panels.

${ }^{*} p<0.05 ;{ }^{*} p<0.01 ;{ }^{* *} p<0.001$ versus respective oil-treated controls; ${ }^{a} p<0.001$ versus all oil-treated groups; ${ }^{b} p<0.01$ versus sham and ovariectomized controls; ${ }^{c} p<0.001$ versus oil or $\mathrm{E}_{2}$-treated sham and ovariectomized rats; ${ }^{\mathrm{d}} p<0.01$ versus sham controls; ${ }^{\mathrm{e}} p<$ 0.05 versus $E_{2}$-treated adrenalectomized-ovariectomized without corticosterone treatment but $p<0.001$ versus other $\mathrm{E}_{2}$-treated non adrenalectomized rats; ${ }^{\mathrm{f}} p<0.01$ versus sham controls; ${ }^{\mathrm{g}} p<0.001$ versus sham controls and $p<0.01$ versus other controls; ${ }^{h} p<0.001$ versus sham controls and $p<0.05$ versus other controls; ${ }^{\mathrm{i}} p<0.05$ versus sham controls; ${ }^{\mathrm{j}} p<0.001$ versus sham controls

trated rats ( $n=4$ in each group). When rats were supplemented with corticosterone $(0.4 \mathrm{mg} /$ day $)$, plasma corticosterone was higher than in sham controls, but still lower than in $E_{2}$-treated sham animals.

In adrenalectomized-ovariectomized rats treated with a high dose of corticosterone $(1 \mathrm{mg} /$ day $)$, plasma corticosterone levels were $226.9 \pm 39.2 \mathrm{ng} / \mathrm{ml}$ in oiltreated rats $(n=6, p<0.001)$ and $294.5 \pm 33.9 \mathrm{ng} / \mathrm{ml}$ in $\mathrm{E}_{2}$-treated rats $(n=6, p<0.001)$, well above physiological values.

Basal Plasma Glucose, Insulin and Glucagon (Table 3, Fig. 1)

Fasting plasma glucose was significantly lowered by adrenalectomy and augmented by corticosterone treatment. This pattern was accentuated by $\mathrm{E}_{2}$ treatment.
Fasting plasma insulin was lowered by adrenalectomy; this was corrected by corticosterone treatment. Oestradiol treatment significantly increased plasma insulin levels in fasted sham-operated and ovariectomized rats but had no effect in adrenalectomized rats, including the corticosterone-supplemented group. In fed rats, the glucose-lowering influence of adrenalectomy was no longer apparent but that of $E_{2}$ treatment persisted (Fig. 1, upper panel). By contrast, the influence of adrenalectomy on plasma insulin levels persisted. It was still lower than plasma insulin concentration in sham controls and in ovariectomized rats. Furthermore, corticosterone treatment restored basal insulin to normal values. A major observation was that oestradiol treatment significantly increased insulin concentration only when the adrenal glands were intact (sham-operated and ovariectomized groups). This was not the case in adrenalectomized-ovariectomized rats. In these rats oestradiol treatment constrastingly induced a significant decrease in plasma insulin (Fig.1, central panel). But when these adrenalectomized-ovariectomized rats were supplemented with corticosterone, the insulin-enhancing effect of oestradiol was partially restored: $44 \pm$ $6 \mathrm{mU} / 1(n=13)$ versus $29 \pm 3 \mathrm{mU} / 1(n=12 ; p<$ $0.05)$. However, this value of $44 \pm 6 \mathrm{mU} / 1$ remained much lower than that measured in $\mathrm{E}_{2}$-treated (nonadrenalectomized) rats $(101 \pm 10 \mathrm{mU} / 1, n=19 ; p<$ 0.001).

Plasma glucagon (Fig. 1, lower panel) concentration was increased by ovariectomy and even more so by adrenalectomy. Corticosterone supplementation induced a slight decrease in plasma glucagon though values remained higher than in other controls. Oestradiol treatment had no effect in sham group but reversed the glucagon rise induced by ovariectomy and reduced the glucagon rise induced by adrenalectomy (Fig. 1, lower panel).

\section{Intravenous Glucose Load (Table 3)}

The pattern of B cell responses to acute IV glucose loading was very similar to that obtained from basal insulin measurements. The areas of the insulin response curve to glucose were significantly higher in $\mathrm{E}_{2}$-treated rats (ovariectomized or not) than in the control group, when adrenal glands were maintained. In adrenalectomizedovariectomized rats, the B cell response was lower than in the sham-operated or ovariectomized groups, and $E_{2}$ treatment lowered it even more: this latter effect contrasted markedly with the effect of $E_{2}$ in other groups. Corticosterone treatment reversed this inhibitory effect of $E_{2}$ in adrenalectomized animals. The reduction in $B$ cell response from the $\mathrm{E}_{2}$-treated adrenalectomized rats, reversed by corticosterone, was particularly apparent for the earlier sampling times following a glucose load (peak value at $2 \mathrm{~min}$ was $93 \pm 13 \mathrm{mU} / 1$ in adrenalectomized-ovariectomized rats versus $34 \pm 9 \mathrm{mU} / 1$ in $\mathrm{E}_{2}$ treated-adrenalectomized-ovariectomized rats; $p<$ 
0.001 and $77 \pm 12 \mathrm{mU} / 1$ with corticosterone supplementation, $p<0.02$ versus $34 \mathrm{mU} / 1$ and NS versus $93 \mathrm{mU} / 1$ ).

The glucose disappearance coefficient in the control group was not significantly different from that obtained in $\mathrm{E}_{2}$-treated intact rats, ovariectomized rats and the ovariectomized- $E_{2}$-treated group. It was significantly lower than the control value in adrenalectomized- $\mathrm{E}_{2}-$ treated rats. These differences in slope of glucose disappearence occurred in spite of the fact that plasma glucose peaks were identical in all groups. Corticosterone treatment reversed the effect of adrenalectomy in oiltreated group but delayed glucose disappearance in $E_{2^{-}}$ treated group.

\section{Insulin Content of Pancreas}

Pancreatic weight was not significantly different between groups and ranged from $778 \pm 41 \mathrm{mg}$ in controls $(n=6)$ to $667 \pm 46 \mathrm{mg}$ in adrenalectomized-ovariectomized- $\mathrm{E}_{2}$-treated rats $(n=6$; NS). The insulin content of pancreas was not significantly affected in control groups $(3.01 \pm 0.28, n=6$ for sham rats; $2.59 \pm 0.21$, $n=11$ for ovariectomized rats; and $2.73 \pm 0.36 \mathrm{U} /$ pancreas, $n=12$ for adrenalectomized-ovariectomized animals). It was significantly lower in the adrenalectomized-ovariectomized- $\mathrm{E}_{2}$-treated rats $(2.32 \pm 0.1 \mathrm{U} /$ pancreas, $n=6 ; p<0.05)$ than in sham-operated control group or sham-operated $\mathrm{E}_{2}$-treated group ( $3.45 \pm$ $0.25, n=7, p<0.01$ ) but not when compared with ovariectomized $\mathrm{E}_{2}$-treated rats $(2.65 \pm 0.18, n=10)$.

\section{Discussion}

Our results confirm that 14 days of treatment with the naturally occurring oestrogen $17-\beta$-oestradiol induce hypoglycaemia, hyperinsulinism and hypoglucagonaemia in the rat. Furthermore, the presence of adrenal glands was necessary for the full expression of these effects on B cells: in adrenalectomized-ovariectomized rats not treated by corticosterone, the oestradiol treatment induced an unexpected decrease in plasma insulin concentration and insulin content of the pancreas.

It is well known that oestradiol treatment can induce a rise in plasma insulin [27-29] and sometimes in pancreatic immunoreactive insulin concentrations [17, $27,29]$. It can also increase the $B$ cell response to glucose in vivo [3, 30] and in vitro [3-5, 29]. The 'trophic effect' of oestrogens on islets has been likened to hyperinsulinism, islet hypertrophy and hyperplasia observed in late pregnancy $[1,31]$. Discrepant influences of oestrogens on the tolerance to intravenous glucose have been documented [32]. These discrepancies can be due to a variety of experimental protocols and oestrogen preparations used, the results being obtained alternatively in intact or in castrated rats. Furthermore, interference of castration and/or oestrogen treatment with other en- docrine glands and other target tissues was not always considered, particularly with regard to progesterone and adrenal steroids. Since endogenous progesterone was augmented by $E_{2}$ treatment, progesterone could have interfered with oestrogen's direct influence on islets $[3,4,33]$. In the present work, specific analysis of the effects of $E_{2}$ on castrated, progesterone-deprived rats tends to exclude progesterone as a mediator of $E_{2}$ effects on the islet. The presence of adrenal glands appeared to be essential for the expression of $E_{2}$ effects on glucoregulation and the B cell. Adrenalectomy not only suppressed the oestradiol-induced hyperinsulinism, but caused a decrease in plasma insulin and in pancreatic insulin content. Reduction in food intake and lower fasting plasma glucose values could account only partly for the negative influence of adrenalectomy and oestradiol on B cell function. Corticosteroid treatment by itself induces hyperinsulinism and islet hyperplasia $[9-12,34]$. High $\mathrm{E}_{2}$ levels in plasma are associated with high corticoid plasma concentrations in most physiological situations [13]. Glucocorticoids might therefore play a role in the $E_{2}$-induced insulin hypersecretion, and the changes in B cells induced by oestrogen treatment might be due partly to the increased adrenocortical activity associated with $17-\beta$-oestradiol treatment.

In contrast with B cells, oestrogens seemed to influence A cells directly. Ovariectomy induced a rise in plasma glucagon; this was corrected by oestradiol treatment, at least relatively, considering that plasma glucose was lower than normal at that time (Fig.1). Similarly, in adrenalectomized-ovariectomized rats whose plasma glucose levels were even lower than in other groups, plasma glucagon increased and this rise was reduced by oestrogen treatment. These results are compatible with a direct suppressive effect of oestradiol on A cells. Consistently, glucagon suppression by glucose is more pronounced in pregnant than non-pregnant women [6], and the A cell response to alanine is reduced in oestrogen-treated rats [8].

Further work is necessary to clarify the mechanism(s) of oestrogen/corticoid interference at the level of islet cells. A permissive action of glucocorticoids may be a prerequisite for the effect of oestradiol on $B$ cells.

Acknowledgements. Novo Laboratories of Paris and Copenhagen are cordially thanked for the generous gift of crystalline insulin, and Choay Laboratories, Paris for kindly donating heparin and iniprol. We express thanks to J.Boillot, S. Mesbah and C.Coirier for their help in hormonal dosages. We are grateful to C. Poudin and J.M. Piaud for technical assistance, and to M.H.Davant for typing the manuscript. This work was supported by grants from DGRST-78-7 2757, Fondation pour la Recherche Médicale Française and CNRS A. I. 2523.

\section{References}

1. Aerts L, Van Assche FA (1975) Ultrastructural changes of the endocrine pancreas in pregnant rats. Diabetologia 11: 285-289

2. Aerts L, Van Assche FA, Faure A, Sutter-Dub M-Th (1980) Effects 
of treatment with progesterone and oestradiol-17- $\beta$ of the endocrine pancreas in ovariectomized rats: ultrastructural variations in the B cells. J Endocrinol. 84: 317-320

3. Costrini NV, Kalkhoff RK (1971) Relative effects of pregnancy, estradiol and progesterone on plasma insulin and pancreatic islet insulin secretion. J Clin Invest 50: 992-999

4. Sutter-Dub M-Th (1979) Effects of pregnancy, progesterone and/or oestradiol on the insulin secretion and pancreatic insulin content in the perfused rat pancreas. Diabete Metab 5:47-56

5. Faure A, Sutter-Dub M-Th (1979) Insulin secretion from isolated pancreatic islets in the female rat. Short and long term oestradiol influence. J Physiol Paris 75:289-295

6. Freinkel N, Metzger BE, Nitzan M, Daniel R, Surmaczynska BZ, Nagel TC (1974) Facilitated anabolism in late pregnancy: some novel maternal compensations for accelerated starvation. In: Malaisse WJ, Pirart J (eds) Proceedings VIII Congress of the International Diabetes Federation, Brussels. Excerpta Medica, Amsterdam, pp 474-478

7. Kalkhoff RK, Kim H (1978) Effects of pregnancy on insulin and glucagon secretion by perfused rat pancreatic islets. Endocrinology 102: 623-631

8. Mandour T, Kissebah AH, Wynn V (1977) Mechanism of oestrogen and progesterone effects on lipid and carbohydrate metabolism: alteration in the insulin: glucagon molar ratio and hepatic enzyme activity. Eur J Clin Invest 7: 181-187

9. Dulin WE, Soret MG (1977) Chemically and hormonally induced diabetes. In: Volk BW, Wellemann KF (eds) The diabetic pancreas, Ballière Tindall, London pp 452-453

10. Malaisse WJ, Malaisse-Lagae F, McCraw EF, Wright PH (1967) Insulin secretion in vitro by pancreatic tissue from normal, adrenalectomized and cortisol treated rats. Proc Soc Exp Biol Med 124: $924-928$

11. Sutter BChJ (1968) Adrenals and plasma insulin in the rat. II. Effect of adrenal cortex. Diabetologia 4: 295-304

12. Lenzen $S$ (1976) The effect of hydrocortisone treatment and adrenalectomy on insulin and glucagon secretion from the perfused rat pancreas Endokrinologie 68: 189-197

13. Audrain M, Beraud G, Lescoat G, Feliot J (1978) Influence du cycle oestrien, de l'ovariectomie et de la lactation sur les variations de la corticostéronémie basale ou après agression chez la ratte. $C$ R Soc Biol 172: 33-37

14. Colby HD, Kitay JI (1974) Interaction of oestradiol and ACTH in the regulation of adrenal corticosterone production in the rat. Steroids $24: 527-536$

15. Doe RP, Zinneman HH, Flink EB, Ulstrom RA (1960) Significance of the concentration of non-protein bound plasma cortisol in normal subjects, Cushing's syndrom, pregnancy and during oestrogen therapy. J Clin Endocrinol Metab 20: 1484-1492

16. Foglia VG, Schuster N, Rodriguez RR (1947) Sex and diabetes. Endocrinology 41: 428 433

17. Haist RE (1965) Effects of steroids on the pancreas. Meth Horm Res 4: 193-233

18. Ingle DJ (1942) The relationship of the diabetogenic effect of diethyl stilbestrol to the adrenal cortex in the rat. Am J Physiol 138: $577-582$

19. Hugget ASG, Nixon DA (1957) Use of glucose oxidase, peroxidase, and $\mathrm{O}$-dianisidine in determination of blood and urinary glucose. Lancet $2: 368-370$
20. Herbert V, Lau KS, Gottlieb CW, Bleicher SJ (1965) Coated charcoal immunoassay of insulin. J Clin Endocrinol Metab 25: 1375-1384

21. Santeusanio F, Faloona GR, Unger RH (1972) Suppressive effect of secretin upon pancreatic alpha-cell function. J Clin Invest 51: 1743-1749

22. Abraham GE, Swerdloff R, Tulchinsky D, Odell WD (1971) Radioimmunoassay of plasma progesterone. $\mathrm{J}$ Clin Endocrinol Metab 32: 619-624

23. Lindner HR, Perel E, Friedlander A, Zeitlin A (1972) Specificity of antibodies to ovarian hormones in relation to the sites of attachment of steroid hapten to the peptide carrier. Steroids 19:357-375

24. Murphy BEP (1967) Some studies of the protein-binding of steroidsand their application of the routine micro and ultra-micro measurement of various steroids in body fluids by CPB radioassay. J Clin Endocrinol Metab 27: 973-990

25. Labrie F, Normand M, Raynaud JP, Fortier C (1965) Two methods for determining the corticosterone-binding characteristics of transcortin. Proc Can Fed Biol Soc 8: 40 (Abstract)

26. Cailla M, Cros GC, Jolu EJP, Delaage M, Depieds RC (1973) Comparison between rat and rabbit anticyclic AMP antibodies specificity. Anal Biochem 56: 383-393

27. Basabe JC, Chieri RA, Foglia VG (1969) Action of sex hormones on the insulinemia of castrated rats. Proc Soc Exp Biol Med 130: $1159-1161$

28. Sutter-Dub M-Th, Faure A, Aerts L, Van Assche FA (1978) Effects of progesterone and 17- $\beta$-oestradiol treatments on the pancreatic $\mathrm{B}$ cell in castrated female rats: biochemical variations. J Physiol Paris 74: 725-730

29. Bailey CJ, Ahmed-Sorour H (1980) Role of ovarian hormones in the long-term control of glucose homeostasis. Effects on insulin secretion. Diabetologia 19:475-481

30. Bailey CJ, Matty AJ (1972) Glucose tolerance and plasma insulin of the rat in relation to the oestrous cycle and sex hormones. Horm Metab Res 4: 266-270

31. Hellman B (1960) The islets of Langerhans in the rat during pregnancy and lactation, with special reference to the changes in the B/A cell ratio. Acta Obstet Gynecol Scand 39: 331-342

32. Carrington LJ, Bailey CJ (1979) Time-dependent effects of orally and intramuscularly administered oestradiol and ethynyl oestradiol on glucose tolerance and insulin secretion in mice. J Endocrinol 80: 76 (Abstract)

33. Howell SL, Tyhurst M, Green IC (1977) Direct effect of progesterone on rat islets of Langerhans in vivo and in tissue culture. Diabetologia 13: $579-583$

34. Vance JE, Kitabchi AE, Buchanan KD, Williams RH (1968) Effects of adrenalectomy on glucagon and insulin release from isolated islets of Langerhans. Clin Res 16: 131 (Abstract)

Received: 13 October 1981

and in revised form: 13 September 1982

Dr. A. Faure

Université de Bordeaux I

UER de Biologie

Laboratoire d'Endocrinologie

Avenue des Facultés

F-33405 Talence Cédex, France 